\author{
Norbert Tomkiewicz \\ Departament Polityki Regionalnej i Funduszy Strukturalnych \\ Urząd Marszałkowski Województwa Małopolskiego
}

\title{
Perspektywy rozwoju przedsiębiorczości w kontekście funduszy strukturalnych Unii Europejskiej
}

Największe dotychczas rozszerzenie Unii Europejskiej 1 maja 2004 roku o 10 państw członkowskich z Europy Środkowo - Wschodniej postrzegane jest jako doniosłe wydarzenie historyczne, uwieńczające kolejny etap wieloletnich procesów integracyjnych w Europie. Akcesja zapoczątkowała korzystny proces budowania strategicznej „wartości dodanej” wzbogacając duchowe i materialne oblicze naszego kontynentu. Wzmocniony został także największy jednolity rynek na świecie, który zwiększył całkowitą liczbę konsumentów do ok. 500 milionów, wytwarzających jedną czwartą światowego bogactwa.

Obecne rozszerzenie stworzyło niepowtarzalną szansę rozwoju cywilizacyjnego, gospodarczego i społecznego dla Polski i pozostałych krajów członkowskich, których poziom zamożności istotnie odbiega od poziomu dotychczasowej unijnej piętnastki. Już pierwszych kilka miesięcy naszego członkostwa wskazuje, że zaczynamy rozumieć i wykorzystywać płynące z Unii Europejskiej szanse, przekładające się na jakościowy rozwój kraju.

Z dniem akcesji włączyliśmy się również w realizację Strategii Lizbońskiej, której zasadniczym celem jest uczynienie z Unii Europejskiej do 2010 roku najbardziej konkurencyjnej, dynamicznej i opartej na wiedzy gospodarki świata. Dlatego też należy oczekiwać, iż członkostwo Polski w Unii pozwoli na stworzenie lepszych warunków dla rozwoju nauki i badań, a także spowoduje dalsze pobudzenie innowacyjności i przedsiębiorczości w naszym kraju.

W związku z tym, w ramach unijnej polityki zaistniała możliwość otrzymania środków z funduszy strukturalnych wspierających rozwój relatywnie uboższych i bardziej zacofanych regionów. Duża część środków transferowanych w ramach funduszy strukturalnych skierowana jest do polskich przedsiębiorstw.

Właściwe każdy rodzaj działalności inwestycyjnej przedsiębiorstwa, mający na celu podniesienie konkurencyjności polskiej gospodarki, a tym samym pośrednio europejskiej, lub zwiększenie potencjału własnego regionu, ma szansę na uzyskanie dofinansowania ze środków UE.

Najpierw jednak trzeba poznać źródła i formy pomocy skierowanej do przedsiębiorstw, potrafić przygotować dojrzałą koncepcję projektu, opanować w sumie prostą umiejętność wypełniania wniosków, wykazać się dużą dozą cierpliwości i wyrozumiałości dla sponsora publicznego. Dlatego też wydaje się, iż fundusze strukturalne są ciekawym, lecz trudnym źródłem finansowania rozwoju przedsiębiorstwa.

\section{SYTUACJA SEKTORA MALYCH I ŚREDNICH PRZEDSIĘBIORSTW W POLSCE}

W Polsce na koniec 2003 roku działało 3581,6 tys. podmiotów gospodarki narodowej tj. o 3,2\% więcej niż przed rokiem. W sektorze publicznym zarejestrowanych było 129,3 tys. 
przedsiębiorstw, natomiast w sektorze prywatnym 3452,3 tys. (GUS, 2003). W efekcie kontynuowania procesów przekształceń własnościowych, zmniejszyła się liczba przedsiębiorstw państwowych. Systematycznie wzrastała natomiast liczba spółek handlowych oraz zakładów osób fizycznych. Liczba podmiotów sektora publicznego, po pierwotnym nieznacznym spadku w latach 1993-95, od 1996 systematycznie rosła, szczególnie dynamicznie w 1998 r. Wzrost ten nie był jednak efektem tworzenia nowych podmiotów, lecz obrazował zmiany organizacyjne $\mathrm{w}$ edukacji, służbie zdrowia i kulturze, związane z przekazywaniem przez administrację rządową organom samorządu terytorialnego zadań z zakresu oświaty publicznej, ochrony zdrowia i opieki społecznej oraz kultury. Samorządy zgodnie ze swoimi kompetencjami usamodzielniły poszczególne jednostki (zespoły szkół, samodzielne zakłady opieki zdrowotnej, samodzielne instytucje kultury). Jednostki te stały się, zgodnie z zasadami metodycznymi rejestru, osobami prawnymi lub jednostkami organizacyjnymi nie mającymi osobowości prawnej, tym samym wpływając na wzrost liczby podmiotów gospodarki narodowej.

Wśród wszystkich podmiotów dominowały przedsiębiorstwa najmniejsze (mikroprzedsiębiorstwa) - do 9 zatrudnionych. Stanowiły one ponad $95 \%$ wszystkich przedsiębiorstw działających na rynku. Podmioty małe 10-49 pracujących stanowiły 3,8\%, a podmioty średnie 50-249 pracujących - 0,8\% wszystkich firm zarejestrowanych w Polsce ${ }^{1}$.

Rozwój sektora MSP w ostatnich latach powoduje stopniowy wzrost udziału tego sektora w tworzeniu produktu krajowego brutto. W 2000 r. udział ten wyniósł 49,4\% i był o 0,9\% wyższy niż w 1999 roku (podobnie jak między rokiem 1998 a 1999). Przyrosty te sa stosunkowo niewielkie w porównaniu $\mathrm{z}$ obserwowanymi we wcześniejszych latach $(2,6 \%$ między 1997 a 1998).

Wskaźnik przedsiębiorczości (mierzony liczbą przedsiębiorstw na 1000 mieszkańców) w Polsce wynosi średnio 94 (ryc. 1).

Ryc. 1. Wskaźnik przedsiębiorczości w województwach w 2003 r.

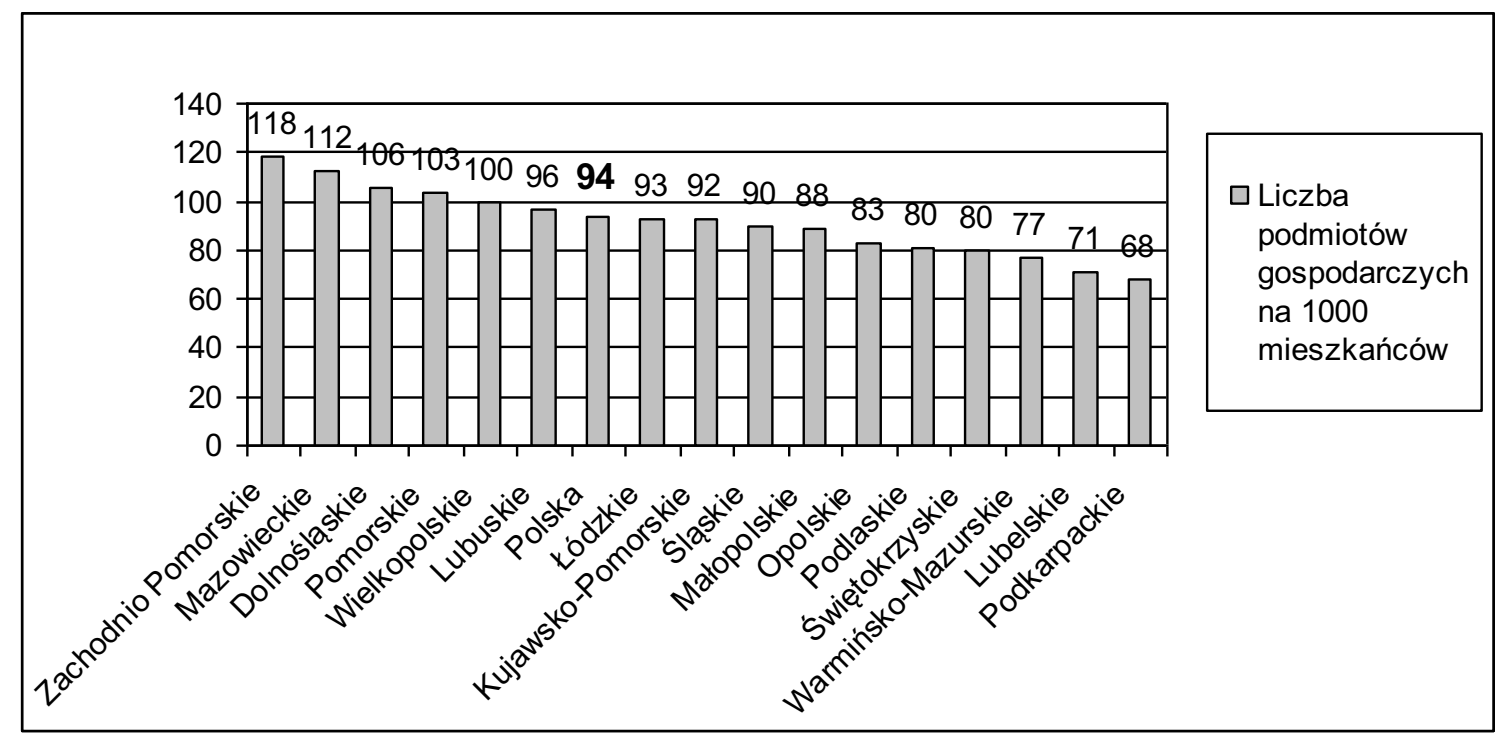

Źródło: Opracowanie własne na podstawie Rocznik statystyczny województw 2004, GUS, Warszawa 2004.

\footnotetext{
${ }^{1}$ Zgodnie z rekomendacją Komisji Europejskiej 2003/361/EC, Ustawa z dnia 2 lipca 2004 r. o swobodzie działalności gospodarczej zawiera zaktualizowane definicje mikro, małego i średniego przedsiębiorcy. Wspólna definicja MSP jest niezwykle istotna, ponieważ jest ona stosowana jako podstawa decyzji w ustawodawstwie unijnym dotyczącym pomocy państwa i funduszy strukturalnych.
} 
Najwyższy wskaźnik w 2003 r. - powyżej średniej krajowej - osiągnęły województwa: zachodniopomorskie (118), mazowieckie (112), dolnośląskie (106), pomorskie (103), wielkopolskie (100) i lubuskie (96), zaś najniższy - lubelskie (71) i podkarpackie (68).

Przestrzenne skupiska MSP powstają więc w obrębie dużych aglomeracji miejskich oraz w okręgach o dobrze rozwiniętym i zróżnicowanym przemyśle. Pogłębia się zatem różnica w aktywności gospodarczej pomiędzy zachodnią, a wschodnią częścią Polski.

Na szczególną uwagę zasługuje sytuacja mikroprzedsiębiorstw - działają one zazwyczaj w jednej branży, w tym szczególnie w handlu, transporcie, budownictwie i obsłudze nieruchomości i firm. Mikroprzedsiębiorstwa zatrudniają ok. 3,2-3,5 mln osób tj. 20\% zatrudnionych w gospodarce. Analiza przychodów i kosztów wskazuje, iż są one rentowne. Nakłady inwestycyjne w mikroprzedsiębiorstwach realizowane są zazwyczaj ze środków własnych, ze względu na ograniczenie płynności, a także niższej ich skłonności do ryzyka.

Chociaż podstawowe wskaźniki charakteryzujące sektor małych i średnich przedsiębiorstw w Polsce są podobne do wskaźników unijnych, to jednak polskie małe i średnie firmy są znacznie słabsze kadrowo, kapitałowo oraz technicznie od firm unijnych.

Małe przedsiębiorstwa cechuje niedostateczny poziom wiedzy dotyczącej prowadzenia przedsiębiorstwa wśród kadry zarządzającej oraz umiejętności praktycznego jej zastosowania.

Ok. 48\% małych i średnich przedsiębiorstw posiada dostęp do Internetu, jednak tylko nieliczne wykorzystują go w prowadzonej działalności gospodarczej.

Również niezadowalająca jest liczba firm stosujących system zarządzania jakością. Obecnie około trzech tysięcy firm posiada certyfikat systemu zarządzania jakością. Są to przede wszystkim firmy średnie. Małe przedsiębiorstwa często nie są zainteresowane uzyskaniem formalnych certyfikatów jakości ponieważ tryb certyfikacji jest kosztowny i czasochłonny, wymagający często włączenia zewnętrznego konsultantów i dokonywania znacznych opłat.

Większość małych i średnich przedsiębiorstw funkcjonuje tylko na rynkach lokalnych i nie jest przygotowana do włączenia się w wymianę międzynarodową. Jedynie ok. 14 tys. firm prowadzi działalność eksportową.

Także pod względem rozwoju technologicznego polskie przedsiębiorstwa pozostają w tyle za firmami unijnymi. Wprowadzenie do produkcji nowego lub zmodernizowanego wyrobu, nowej lub zmodernizowanej technologii związane jest $\mathrm{z}$ poważnymi wydatkami: kosztem zakupu licencji lub know-how, kosztem prac badawczo-rozwojowych, kosztem uruchomienia prototypu i wdrożenia, kosztem certyfikacji itd. Koszty te są bardzo wysokie jak na możliwości małych i średnich firm.

Najpoważniejszą barierę rozwoju przedsiębiorstw stanowi brak środków finansowych na modernizację przedsiębiorstw.

Wśród małych i średnich przedsiębiorstw utrzymuje się tendencja do finansowania rozwoju przede wszystkim w oparciu o środki własne. Skłonność taką deklaruje ponad $90 \%$ firm z sektora $\mathrm{MSP}^{2}$. Z jednej strony na postawę taką wpływają uwarunkowania makroekonomiczne, które określają rynkowe warunki funkcjonowania przedsiębiorstw, $z$ drugiej natomiast czynniki wewnętrzne, w tym przede wszystkim wielkość majątku, jakim dysponuje przedsiębiorstwo. Czynniki te decydują m.in. o dostępności małych i średnich przedsiębiorstw do zewnętrznych źródeł finansowania.

Głównymi problemami limitującym dostęp MSP do kredytów bankowych jest często spotykany zwłaszcza u małych firm i tym bardziej osób rozpoczynających działalność gospodarczą brak historii kredytowej oraz wiarygodności kredytowej oznaczającej brak odpowiedniego zabezpieczenia kredytu. Dla firm mikro barierą jest również złożoność wniosków

\footnotetext{
${ }^{2}$ Badanie Fundacji Edukacji i Badań Naukowych Centrum Badań Marketingowych - Indicator, zrealizowane we wrześniu 2000 roku.
} 
kredytowych oraz stosowanie przez nie uproszczonych form księgowości, co utrudnia bankom stosowanie standardowych metod oceny zdolności kredytowej.

\section{INNOWACYJNOŚĆ PODSTAWĄ ROZWOJU PRZEDSIĘBIORSTWA}

Z wielu analiz wynika, że innowacyjność polskiej gospodarki i polskich przedsiębiorstw jest niska. Małe i średnie przedsiębiorstwa w Polsce mają duże trudności z wprowadzaniem rozwiązań innowacyjnych przede wszystkim z powodu wysokich kosztów opracowania i wdrożenia innowacji. Ponadto brak rozwiniętej infrastruktury komercjalizacji nauki i techniki w Polsce powoduje, że inwestowanie w nowe technologie i tworzenie nowych firm jest związane ze zbyt wysokim ryzykiem, hamującym w konsekwencji wykorzystanie badań naukowych $w$ gospodarce. W Polsce wydatki na badania i rozwój kształtują się poniżej $0,6 \%$ PKB, przy czym nieco ponad połowa $\mathrm{z}$ nich pochodzi ze źródeł publicznych, mniej niż połowa ze źródeł prywatnych. W przeliczeniu na jednego badacza wydatki w sferze B+R wynoszą w Polsce zaledwie 21 tys. euro, podczas gdy dla UE-25 - 156 tys. euro, a dla UE-15 171 tys. euro (GUS, 2004). W konsekwencji tak niskich nakładów mamy do czynienia z:

- brakiem instytucji pomostowych pomiędzy obszarem nauki a przedsiębiorstwami,

- $\quad$ spadkiem zatrudnienia w sferze B+R w jednostkach badawczo-rozwojowych,

- wzrostem dekapitalizacji aparatury naukowo-badawczej.

Taki stan rzeczy ma wpływ na wyjątkowo niską liczbę patentów uzyskiwaną przez Polskie firmy na poziomie krajowym a zwłaszcza na poziomie europejskim. W zakresie działalności patentowej w Polsce w 2002 r. zostało zgłoszonych przez rezydentów 2313 wynalazków do ochrony patentowej, a udzielonych zostało 834 patenty. Liczba wynalazków zgłoszonych w Polsce przez wynalazców zagranicznych (nierezydentów) wyniosła 4295 (Urząd Patentowy udzielił im 1437 patentów). Liczba wynalazków polskich zgłoszonych do rejestracji zagranicą (dane na rok 2000) wyniosła 6327 (tzw. krajozgłoszeń), a udzielonych patentów - 123. Polska słabo wypada w ilości wynalazków na 1 mln ludności zgłaszanych w Europejskim Urzędzie Patentowym (EPO). Wartość tego wskaźnika wynosi 3, podczas gdy średnia dla UE-15 - 161. Niekorzystnie również wypadają porównania dotyczące sfery badawczo-rozwojowej z pozostałymi nowo przyjętymi do UE krajami, co obrazuje tabela 1.

Tab. 1. Wybrane wskaźniki charakteryzujące funkcjonowanie nauki i techniki w nowych krajach członkowskich UE.

\begin{tabular}{|c|c|c|c|c|c|}
\hline Kraje & $\begin{array}{l}\text { Średni roczny } \\
\text { wzrost PKB w } \\
\% \text { w latach } \\
1995-2000\end{array}$ & $\begin{array}{l}\text { Relacja nakła- } \\
\text { dów na dzia- } \\
\text { łalność B+R do } \\
\text { PKB w } 2000 \text { r. }\end{array}$ & $\begin{array}{l}\text { Wynalazki zgło- } \\
\text { szone do opaten- } \\
\text { towania w EPO } \\
\text { na milion ludno- } \\
\text { ści w } 2001 \mathrm{r} \text {. }\end{array}$ & $\begin{array}{l}\text { Publikacje } \\
\text { naukowe na } \\
\text { milion ludności } \\
\text { w } 1999 \mathrm{r} \text {. }\end{array}$ & $\begin{array}{l}\text { Udział ekspor- } \\
\text { tu wysokiej } \\
\text { techniki } \\
\text { w eksporcie } \\
\text { ogółem w \% } \\
\text { w } 2001 \mathrm{r} \text {. }\end{array}$ \\
\hline Cypr & 3,78 & 0,26 & 14 & 170 & 1,5 \\
\hline Estonia & 4,90 & 0,66 & 11 & 330 & 14,6 \\
\hline Litwa & 3,33 & 0,60 & 2 & 127 & 2,9 \\
\hline Łotwa & 5,28 & 0,48 & 8 & 143 & 2,2 \\
\hline Malta & 4,37 & & - & 67 & 59,4 \\
\hline Polska & 5,14 & 0,67 & 3 & 221 & 2,7 \\
\hline Czechy & 1,22 & 1,33 & 11 & 352 & 9,2 \\
\hline Słowacja & 3,78 & 1,52 & 41 & 293 & 3,7 \\
\hline Słowenia & 4,34 & 0,67 & 6 & 577 & 4,8 \\
\hline Węgry & 4,02 & 0,80 & 19 & 370 & 20,7 \\
\hline UE-15 & 2,63 & 1,93 & 161 & 755 & 19,8 \\
\hline
\end{tabular}

Źródło: Nauka i technika w 2003 roku, GUS 2004 r. 
Dla poprawy innowacyjności polskich przedsiębiorstw w czerwcu 2002 r podjęto inicjatywę uruchomienia projektów celowych dla Regionalnych Strategii Innowacji (RSI). Zadaniem RSI jest wspomaganie władz lokalnych we wdrażaniu efektywnego systemu wspierania innowacyjności w regionach, budowanie partnerstwa i współpracy pomiędzy jednostkami naukowymi i przemysłem oraz wzmocnienie i wykorzystanie potencjału regionalnego sektora akademickiego i naukowo-badawczego dla rozwoju przedsiębiorczości i wzmocnienia konkurencyjności.

RSI zostały wpisane w priorytety Narodowego Planu Rozwoju 2004-2006 dotyczącego restrukturyzacji bazy ekonomicznej regionów i tworzenia warunków jej dywersyfikacji oraz rozwoju międzynarodowej współpracy regionów. Istotą projektów jest nawiązanie współpracy między władzami samorządowymi regionu a przedsiębiorstwami, instytucjami badawczymi, uczelniami, dostawcami usług finansowych i doradczych oraz instytucjami użyteczności publicznej, a następnie budowa strategii innowacyjnej. Ponadto celem projektów jest upowszechnienie możliwości efektywnego wykorzystywania funduszy strukturalnych na badania i rozwój w regionie oraz promocja innowacyjnego wizerunku regionu.

Według stanu na 31 grudnia 2003 r. zostało zawartych 10 umów z urzędami marszałkowskimi województw na dofinansowanie projektów celowych w ramach RSI. Według kolejności dat zawierania umów są to następujące województwa: lubelskie, lubuskie, łódzkie, małopolskie, świętokrzyskie, pomorskie, podkarpackie, kujawsko-pomorskie, podlaskie i dolnośląskie. Projekty pozostałych sześciu województw (opolskiego, śląskiego, warmińskomazurskiego, wielkopolskiego, zachodniopomorskiego i mazowieckiego) realizowane są w ramach 5. Programu Ramowego Unii Europejskiej.

\section{GŁÓWNE PROGRAMY WSPIERAJACE ROZWÓJ PRZEDSIĘBIORCZOŚCI OD 2004 R.}

Fundusze strukturalne mogą finansować projekty związane z rozwojem przedsiębiorstw pod warunkiem, że pomoże to firmom podnieść swoją pozycję na rynku lub np. zmniejszyć obciążenia dla środowiska. Dotacje mogą być przyznawane jedynie zgodnie z zasadami dopuszczalności pomocy publicznej dla przedsiębiorstw.

Przepisy te zostały wprowadzone na terenie całej Unii Europejskiej w celu ochrony zasady konkurencji. W praktyce wynika z nich, że firmy z Warszawy, Gdańska, Krakowa, Wrocławia czy Poznania otrzymają mniejszą pomoc (dotację) niż przedsiębiorstwa pochodzące $\mathrm{z}$ pozostałych regionów kraju. Ponadto przy przyznawaniu dotacji uwzględniane są wszystkie dotacje, które otrzymuje dany przedsiębiorca zarówno ze środków UE, jak również z pieniędzy krajowych. Bierze się też pod uwagę pomoc pozafinansową (np. ulgi podatkowe). Na skutek takiego rozwiązania firmy funkcjonujące w specjalnych strefach ekonomicznych dostaną mniejszą pomoc, niż te pozostające poza strefami.

Przedsiębiorcy mogą otrzymać środki na inwestycje związane z rozwojem firmy, a także na szkolenia i doradztwo. W zależności od przeznaczenia dotacji różna jest wysokość dofinansowania. Pomoc dla firm zróżnicowana jest również w zależności od ich wielkości.

Zintegrowany Program Operacyjny Rozwoju Regionalnego (ZPORR) jest jednym z siedmiu programów operacyjnych, które posłużą do realizacji Narodowego Planu Rozwoju (NPR) / Podstaw Wsparcia Wspólnoty na lata 2004-2006 (NPR/CSF). Program ten rozwija cele NPR, określając priorytety, kierunki i wysokość środków przeznaczonych na realizację polityki regionalnej państwa, które będą uruchamiane z udziałem funduszy strukturalnych w pierwszym okresie członkostwa Polski w Unii Europejskiej.

Celem strategicznym ZPORR jest tworzenie warunków wzrostu konkurencyjności regionów oraz przeciwdziałanie marginalizacji niektórych obszarów w taki sposób, aby sprzyjać długofalowemu rozwojowi gospodarczemu kraju, jego spójności ekonomicznej, społecznej i terytorialnej oraz integracji z Unią Europejską. Program ten powstał we współpracy z samorządami województw i będzie realizowany na terenie całego kraju. Niektóre działania 
programu mają charakter lokalny, tzn. będą z nich mogły korzystać jedynie wybrane obszary (np. obszary wiejskie, miasta).

Na realizację Zintegrowanego Programu Rozwoju Regionalnego 2004-2006 zostanie zaangażowanych 4230,1 mln euro, w tym 2968,5 mln euro ze strony zasobów funduszy strukturalnych (NPR, 2004).

Celem Sektorowego Programu Operacyjnego Wzrost Konkurencyjności Przedsiębiorstw (SPO WKP) jest poprawa pozycji konkurencyjnej polskiej gospodarki funkcjonującej w warunkach otwartego rynku. Będzie on osiągany poprzez koncentrację środków finansowych kierowanych bezpośrednio do sektora przedsiębiorstw, sektora naukowobadawczego oraz instytucji otoczenia biznesu, na najbardziej efektywne projekty i przedsięwzięcia, gwarantujące wzrost innowacyjności produktowej i technologicznej. Niski poziom konkurencyjności polskiej gospodarki wymusza konieczność podjęcia działań wspierających rozwój firm, które przede wszystkim są zdolne do tworzenia i absorbowania innowacji o największym potencjale wzrostu oraz możliwościach eksportowych.

Plan finansowy dla SPO WKP przewiduje wkład ze strony funduszy strukturalnych na poziomie 1251,1 mln euro. Szacowane dofinansowanie ze środków krajowych publicznych wyniesie 461,4 mln euro, natomiast wkład sektora prywatnego 1147,6 mln euro.

Poniżej przedstawione zostały ważniejsze działania wspierające przedsiębiorczość w ramach Zintegrowanego Programu Operacyjnego Rozwoju Regionalnego i Sektorowego Programu Operacyjnego Wzrost Konkurencyjności Przedsiębiorstw.

\section{DZIALANIE 2.5 ZPORR „PROMOCJA PRZEDSIĘBIORCZOŚCI”}

W ramach projektów mogą być przewidziane różne formy pomocy, które mają za zadanie wspomagać przedsiębiorcę zarówno w momencie zakładania firmy, jak i w okresie początków jej funkcjonowania.

To źródło finansowania przeznaczone jest głównie dla organizacji pozarządowych, instytucji rynku pracy, otoczenia biznesu oraz szkoleniowych i uczelni. Mogą one aplikować o dotacje na prowadzenie działań związanych z promocją przedsiębiorczości w szczególności wśród młodzieży, osób odchodzących z rolnictwa oraz osób zagrożonych restrukturyzacją.

W ramach działania realizowany będzie jeden typ projektu, który będzie obejmował następujące formy wsparcia:

1) Swiadczenie usług doradczych i szkoleniowych wspierających zakładanie i prowadzenie działalności gospodarczej, polegających na:

- organizowaniu usług informacyjnych z zakresu podstawowych zasad prowadzenia działalności gospodarczej,

- organizowaniu grupowych i indywidualnych usług doradczych i szkoleniowych, umożliwiających nabywanie umiejętności niezbędnych dla prowadzenia działalności gospodarczej,

- organizowaniu szkoleń ukierunkowanych na podnoszenie kwalifikacji zawodowych, połączonych z indywidualnym doradztwem (coaching) jako częścią szkolenia,

- zapewnieniu opieki indywidualnego doradcy, który wsparciem obejmie określoną grupę osób, udzielając im pomocy doradczej, np. w diagnozie potrzeb przedsiębiorstwa i zdefiniowaniu rodzaju oraz zakresu potrzebnej pomocy, ułatwianiu dostępu do zaawansowanych usług doradczych i szkoleniowych, korzystaniu z instrumentów wsparcia dostępnych dla mikroprzedsiębiorców,

- organizowaniu przedsięwzięć grupowych z udziałem nowozarejestrowanych mikroprzedsiębiorców.

2) Rozpowszechnianie dobrych praktyk i metod rozwoju. 
3) Przekazywanie pomocy finansowej przysługującej po zarejestrowaniu się mikroprzedsiebiorcy w formie:

- wsparcia pomostowego

- jednorazowej dotacji inwestycyjnej na rozwój działalności.

Wsparcie pomostowe jest bezpośrednią, bezzwrotną pomocą kapitałową wspomagającą ,przetrwanie” przedsiębiorcy do uzyskania przez niego płynności finansowej. Beneficjent otrzymuje, przez okres pierwszych 6 miesięcy działalności (liczonych od zarejestrowania firmy zgodnie $\mathrm{z}$ obowiązującymi przepisami), pomoc kapitałową $\mathrm{w}$ formie comiesięcznych dotacji w wysokości 700 zł (kwota zbliżona do wysokości obligatoryjnych opłat dla przedsiębiorcy nie zatrudniającego pracowników, ponoszonych niezależne od poziomu przychodów w postaci składki na ubezpieczenia społeczne, ubezpieczenie zdrowotne oraz fundusze pozaubezpieczeniowe). W przypadku utrzymującej się i udokumentowanej słabej kondycji finansowej przedsiębiorcy korzystającego ze wsparcia pomostowego, istnieje możliwość przedłużenia jego udzielania o kolejne $6 \mathrm{~m}$-cy (jednakże nie dłużej niż do 12 miesiąca funkcjonowania firmy), o ile umożliwi to osiągnięcie płynności finansowej.

Jednorazowa dotacja inwestycyjna na rozwój działalności polega na udzieleniu jednorazowego wsparcia kapitałowego ułatwiającego sfinansowanie pierwszych wydatków umożliwiających funkcjonowanie nowopowstałego mikroprzedsiębiorstwa (np. zakup drobnego sprzętu, mebli itp.). Wysokość dotacji uzależniona jest od wykazanych potrzeb związanych z planowaną inwestycją, jednakże maksymalnie wynosi ona 5000 euro. Ze środków dotacji pokrywane jest $75 \%$ kosztów kwalifikowalnych inwestycji, a pozostałe $25 \%$ ponosi przedsiębiorca ze środków własnych.

\section{DZIALANIE 3. 4 ZPORR „MIKROPRZEDSIĘBIORSTWA”}

Celem działania jest zwiększenie konkurencyjności mikroprzedsiębiorstw poprzez ułatwienie przedsiębiorcom dostępu do specjalistycznego doradztwa oraz zwiększenie zdolności inwestycyjnej w początkowym okresie funkcjonowania przedsiębiorstw.

Działanie 3. 4 ZPORR skierowane jest do przedsiębiorców, którzy rozpoczęli działalność gospodarczą nie wcześniej niż 36 miesięcy przed dniem złożenia wniosku aplikacyjnego. Dodatkowe warunki jakie musza spełniać przedsiębiorcy to m.in.:

- w ostatnim zakończonym roku obrotowym oraz w roku obrotowym, w którym składany jest wniosek średnioroczne zatrudnienie nie może być większe niż 10 pracowników,

- roczny obrót netto ze sprzedaży towarów, wyrobów i usług oraz operacji finansowych nie może przekraczać równowartości w złotych 2 milionów euro, lub suma aktywów bilansu przedsiębiorstwa na koniec ostatniego roku obrotowego nie może przekroczyć równowartości w złotych 2 milionów euro.

Poniższy algorytm pozwala na oszacowanie liczby mikroprzedsiębiorstw, które będą stanowić docelowo grupę beneficjentów zainteresowanych skorzystaniem z działania 3. 4 ZPORR „Mikroprzedsiębiorstwa", (tabela 2).

$\mathrm{N}$ - liczba firm w poszczególnych województwach w 2003 r. (podmioty gospodarki narodowej wg REGON w 2003 r.)

a - współczynnik firm aktywnych - około 0,5

b - średni przyrost netto liczby firm w skali roku kształtuje się w przedziale $0,045-0,05$ (przyjęto - 0,047)

c - współczynnik określający liczbę mikroprzedsiębiorstw do ogółu MSP - około 0,95

\footnotetext{
${ }^{3} \mathrm{~W}$ obliczeniach przyjęto dane statystyczne (współczynniki) z raportu opracowanego przez PARP „MSP w Polsce, Statystyka w układzie regionalnym” oraz z raportu Instytutu Badań nad Gospodarką Rynkową - „Usługi wspierające mikroprzedsiębiorstwa, małe przedsiębiorstwa i samozatrudnionych raport małopolski”.
} 
d - współczynnik korzystania z usług wsparcia w populacji mikroprzedsiębiorstw - 0,17

stąd można wyznaczyć:

$\mathrm{X}$ - liczba mikroprzedsiębiorstw funkcjonujących nie dłużej niż 3 lata

Y - przewidywana liczba mikroprzedsiębiorstw, które skorzystają z usług wsparcia

$$
\begin{gathered}
\mathrm{X}=N \boldsymbol{N} \boldsymbol{x} \times(3 b) x c \\
\mathrm{Y}=X x d
\end{gathered}
$$

Tab. 2. Liczba potencjalnych beneficjentów w poszczególnych województwach, którzy skorzystają z pomocy $\mathrm{w}$ ramach działania 3. 4 ZPORR oraz średnia wielkość wsparcia.

\begin{tabular}{|l|l|r|r|r|r|}
\hline Lp. & \multicolumn{1}{|c|}{ Województwo } & $\mathrm{N}$ & $\mathrm{X}$ & $\mathrm{Y}$ & $\begin{array}{c}\text { Średnia wielkość } \\
\text { wsparcia na 1 } \\
\text { mikroprzedsięb. }\end{array}$ \\
\hline 1 & Dolnośląskie & 305888 & 20487 & 3483 & 1481 \\
\hline 2 & Kujawsko-Pomorskie & 191029 & 12794 & 2175 & 849 \\
\hline 3 & Lubelskie & 154849 & 10371 & 1763 & 2399 \\
\hline 4 & Lubuskie & 97313 & 6518 & 1108 & 1525 \\
\hline 5 & Łódzkie & 241440 & 16170 & 2749 & 1143 \\
\hline 6 & Małopolskie & 287816 & 19276 & 3277 & 1195 \\
\hline 7 & Mazowieckie & 575598 & 38551 & 6554 & 936 \\
\hline 8 & Opolskie & 87412 & 5854 & 995 & 1577 \\
\hline 9 & Podkarpackie & 142682 & 9556 & 1625 & 2364 \\
\hline 10 & Podlaskie & 96938 & 6492 & 1104 & 2697 \\
\hline 11 & Pomorskie & 226329 & 15158 & 2577 & 1267 \\
\hline 12 & Śląskie & 424031 & 28399 & 4828 & 1283 \\
\hline 13 & Świętokrzyskie & 103679 & 6944 & 1180 & 2287 \\
\hline 14 & Warmińsko-Mazurskie & 110390 & 7393 & 1257 & 3154 \\
\hline 15 & Wielkopolskie & 335573 & 22475 & 3821 & 785 \\
\hline 16 & Zachodniopomorskie & 200626 & 13437 & 2284 & 1254 \\
\hline OGOŁEM POLSKA: & 3581593 & 239877 & 40779 & 1385 \\
\hline
\end{tabular}

Źródło: Opracowanie własne na podstawie Rocznik statystyczny województw 2004, GUS, Warszawa 2004.

W ramach działania 3.4 ZPORR beneficjenci mogą ubiegać się o dofinansowanie ze środków publicznych na dwa typy projektów:

1) Specjalistyczne usługi doradcze dla mikroprzedsiębiorstw ${ }^{4}$.

Pierwszy typ projektów ma na celu wprowadzenie innowacyjności w przedsiębiorstwie oraz zwiększenie jego konkurencyjności poprzez:

- opracowanie strategii umieszczenia produktu na nowym rynku zbytu,

- wprowadzenie na rynek nowego produktu,

- zdobycie nowej grupy klientów,

- racjonalizację przepływów finansowych, towarów, materiałów, informacji wewnątrz przedsiębiorstwa,

- komputeryzację, racjonalizację logistyki sprzedaży towarów i usług,

- poprawę zarządzania wewnątrz firmy, itp.

W ramach projektów doradczych wykonawcami usług doradczych mogą być firmy, organizacje i instytucje, które uzyskały akredytację Polskiej Agencji Rozwoju Przedsiębior-

\footnotetext{
${ }^{4}$ Specjalistyczne usługi doradcze nie obejmują doradztwa stałego, związanego z codzienną działalnością operacyjną przedsiębiorstwa, takiego jak doradztwo podatkowe, prawne i marketingowe.
} 
czości (PARP) dla tego typu usług w ramach Krajowego Systemu Usług dla Małych i Średnich Przedsiębiorstw.

2) Dotacje inwestycyjne dla mikroprzedsiębiorstw.

Wspierane będą projekty, które otrzymają dofinansowanie inwestycji związanych z:

- rozbudową lub nabyciem przedsiębiorstwa,

- rozszerzeniem zakresu działalności gospodarczej,

- rozpoczęciem w przedsiębiorstwie działań obejmujących dokonywanie zasadniczych zmian produkcji bądź procesu produkcyjnego,

- zmianą wyrobu, usługi oraz sposobu świadczenia usług,

- unowocześnieniem wyposażenia niezbędnego do prowadzenia działalności gospodarczej firmy,

- modernizacją środków produkcji.

Beneficjentem końcowym dla działań 2.5 i 3.4 ZPORR jest samorząd województwa w województwach: małopolskim, mazowieckim, podlaskim i świętokrzyskim który pełni funkcję instytucji wdrażającej, natomiast w pozostałych samorząd województwa powierzył realizację działania innym instytucjom, głównie Regionalnym Instytucjom Finansującym $(\mathrm{RIF})^{5}$.

W latach 2004-2006 Polska będzie mogła wykorzystać na działanie 2. 5 - 45641589 euro z Europejskiego Funduszu Społecznego (EFS), a na działanie 3.4 - 56494658 euro (ryc. 2) ze środków Europejskiego Funduszu Rozwoju Regionalnego (EFRR).

Ryc. 2. Indykatywna alokacja funduszy strukturalnych w podziale na działania 2.5 i 3.4 ZPORR wg województw (w euro).

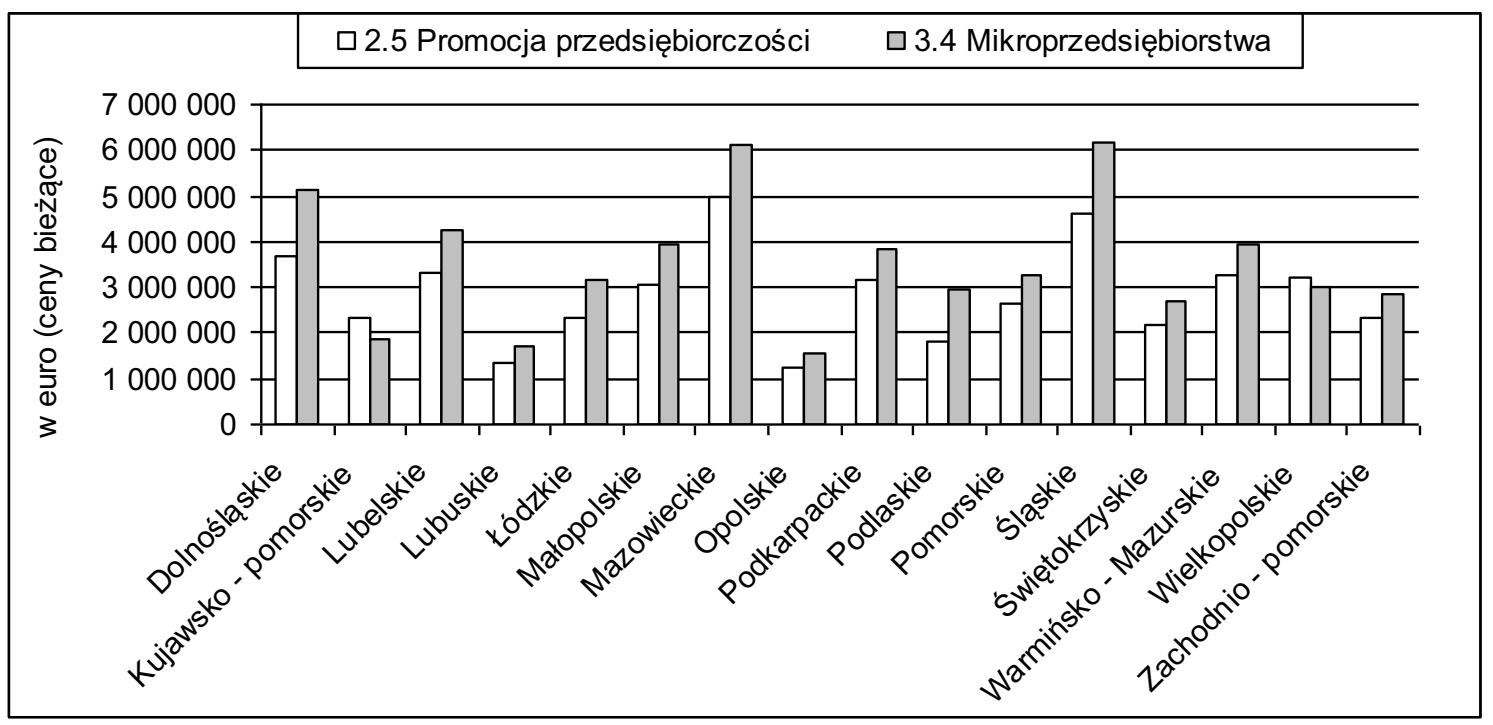

Źródło: Opracowanie własne na podstawie: Uzupełnienie Zintegrowanego Programu Operacyjnego Rozwoju Regionalnego 2004-2006, załącznik do Rozporządzenie Ministra Gospodarki i Pracy z dnia 25 sierpnia 2004 r. (Dz. U. Nr 200 poz. 2051).

\footnotetext{
${ }^{5}$ Regionalne Instytucje Finansujące są wojewódzkim partnerem PARP, współpracującym przy wdrażaniu polityki sektorowej, adresowanej do MSP w regionie. Wyłonione w drodze konkursu, spośród istniejących instytucji regionalnych, koncentrują swoje działania na takich obszarach jak: zarządzanie regionalnymi programami rozwoju przedsiębiorczości, administrowanie w imieniu PARP „sektorowymi" instrumentami wsparcia MSP w regionie, udzielanie podstawowej pomocy doradczej dla przedsiębiorstw w ramach prowadzonego PKD.
} 


\section{DZIALANIE 2.1 SPO WKP „WZROST KONKURENCYJNOŚCI MALYCH I ŚREDNICH PRZED- SIĘBIORSTW POPRZEZ DORADZTWO}

Działanie realizowane jest przez PARP (instytucja wdrażająca) we współpracy z RIF. Beneficjentami są MSP posiadający siedzibę na terytorium Rzeczypospolitej Polskiej, z wyłączeniem mikroprzedsiębiorców innych niż mikroprzedsiębiorcy wykonujący działalność gospodarczą od co najmniej 3 lat lub opartą na wykorzystaniu zaawansowanych technologii o znaczącym potencjale rynkowym ${ }^{6}$.

Realizacja działania polegać będzie na udzielaniu dotacji dla przedsiębiorstw, przeznaczonych na pokrycie części kosztów usług doradczych świadczonych przez akredytowanych wykonawców lub wykonawców wyłonionych w drodze postępowania o udzielenie zamówienia publicznego zgodnie z ustawą Prawo zamówień publicznych (dotyczy mikroprzedsiębiorstw prowadzacych działalność oparta na wykorzystaniu zaawansowanych technologii, które ubiegają się o wsparcie ze środków publicznych przekraczające $50 \%$ wydatków kwalifikowanych) i dotyczących następujących rodzajów projektów ${ }^{7}$ :

- doradztwa w zakresie prowadzenia przedsiębiorstwa na terenie UE,

- doradztwa w zakresie jakości (m.in. projektowania, wdrażania i doskonalenia systemów zarządzania jakością, zarządzania środowiskowego, uzyskiwania i odnawiania certyfikatów zgodności dla wyrobów, usług, surowców, maszyn i urządzeń, aparatury kontrolno - pomiarowej lub kwalifikacji personelu),

- doradztwa związanego z innowacjami i nowymi technologiami (m.in. wdrażanie strategii rozwoju przedsiębiorstwa w oparciu o nowe technologie i rozwiązania innowacyjne, tworzenie przedsiębiorstw opartych na wykorzystaniu zaawansowanych technologii, wykorzystywanie technologii informatycznych w przedsiębiorstwie),

- $\quad$ wprowadzania przez przedsiębiorcę produktów na nowe rynki zagraniczne,

- tworzenia sieci kooperacyjnych przedsiębiorstw,

- łączenia się przedsiębiorstw,

- pozyskiwania zewnętrznego finansowania na rozwój działalności gospodarczej.

Maksymalna wysokość wsparcia udzielonego w ramach działania może wynieść do $50 \%$ wydatków kwalifikowanych, przy czym dofinansowanie ze środków EFRR wyniesie $35 \%$ kwalifikujących się wydatków, a z budżetu państwa - 15\%. W przypadku projektów doradztwa dla mikroprzedsiębiorstw prowadzących działalność gospodarczą $\mathrm{w}$ oparciu o wykorzystanie zaawansowanych technologii o znaczącym potencjale rynkowym wkład publiczny może wynosić do $100 \%$ wydatków kwalifikowanych. W obu przypadkach kwota wsparcia danego projektu doradczego nie może być niższa niż 2500 zł i nie wyższa niż 250 tys. zł.

Budżet na lata 2004-2006 dla działania 2.1 wynosi $66,27 \mathrm{mln}$ euro, w tym $23,17 \mathrm{mln}$ euro pochodzi ze EFRR,9,90 mln euro z budżetu państwa, natomiast sektor prywatny zaangażuje kwotę ok. 33,20 mln euro ${ }^{8}$.

\section{DZIALANIE 2. 3 SPO WKP, „WZROST KONKURENCYJNOŚCI MALYCH I ŚREDNICH PRZED- SIĘBIORSTW POPRZEZ INWESTYCJE"}

Projekty wspierane w ramach działania obejmują inwestycje określone w rozporządzeniu Komisji Europejskiej Nr 70/2001, mające na celu zmodernizowanie niekonkurencyjnego i zdekapitalizowanego majątku w przedsiębiorstwach usługowych i produkcyjnych.

\footnotetext{
${ }^{6}$ Podobnie grupę beneficjentów określono dla działania 2. 3 SPO WKP.

${ }^{7}$ Przedsiębiorcy mogą starać się o dotacje w drodze konkursu zamkniętego, który będzie ogłaszany 4-6 razy w roku.

${ }^{8}$ Przewiduje się, że tego typu dotacje otrzyma ponad 16000 firm z różnych branż.
} 
Projekty realizujące działania nowe, modernizacyjne oraz dostosowawcze będą szczegółowo badane pod kątem zgodności z ww. rozporządzeniem.

W szczególności wspierane są przedsięwzięcia związane z:

- modernizacją (wprowadzanie znaczącej zmiany produktu lub procesu produkcyjnego),

- wdrażaniem wspólnych przedsięwzięć inwestycyjnych podejmowanych przez przedsiębiorstwa,

- zakupem wyników prac badawczo-rozwojowych i/lub praw własności przemysłowej,

- wdrażaniem technologii i produktów innowacyjnych,

- zastosowaniem narzędzi elektronicznych,

- zastosowaniem technologii informatycznych i komunikacyjnych (ICT) w zarządzaniu,

- dostosowywaniem technologii i produktów do wymagań dyrektyw unijnych, zwłaszcza norm w zakresie BHP.

W działaniu wyznaczono minimalny i maksymalny próg wsparcia. Kwota wsparcia w zakresie inwestycji nie może być niższa niż 10 tys. zł i nie wyższa niż 1250 tys. zł (w ramach danego projektu). Wsparcie w zakresie inwestycji przekraczające 125 tys. zł jest udzielane pod warunkiem, że beneficjent sfinansuje inwestycję kredytem lub środkami pieniężnymi pochodzącymi z funduszu inwestycyjnego, w kwocie stanowiącej co najmniej $25 \%$ kwoty wsparcia. Z obowiązku zaciągnięcia kredytu zwolnieni są beneficjenci, którzy sfinansują projekt z wykorzystaniem leasingu nowych środków trwałych, prowadzącego do przeniesienia własności tych środków na korzystającego, niezależnie od wielkości wydatków kwalifikujących się do objęcia wsparciem.

Maksymalna wysokość pomocy publicznej wynosi 50\% kwalifikowanych wydatków inwestycji, w zależności od maksymalnej intensywności pomocy publicznej dla danego regionu, określonej odrębnymi przepisami. Dla projektów realizowanych na obszarze podregionów: Warszawa lub Poznań wynosi ona 30\% (EDN), Wrocław, Kraków i Trójmiasto Gdańsk-Gdynia-Sopot - 40\% (EDN), natomiast dla projektów realizowanych na pozostałych terenach Polski wynosi 50\% (EDN) ${ }^{9}$.

W latach 2004-2006 na realizację działania 2.3 przewidziano 718,03 $\mathrm{mln}$ euro, z czego 359,03 mln euro to wkład publiczny (251,33 mln euro - EFRR,107,70 mln euro budżetu państwa). Pozostała część tj. ok. 359,00 mln euro to udział środków prywatnych.

\section{JAK POPRAWNIE NAPISAĆ WNIOSEK O DOTACJĘ Z FUNDUSZY STRUKTURALNYCH}

Aby otrzymać pieniądze z funduszy strukturalnych, należy odpowiednio przygotować projekt, w którym uzasadni się i opisze sposób wykorzystania przyznanych środków. Przed wnioskodawcą mogą pojawić się pewne bariery, wynikające najczęściej z nieznajomości kontekstu merytorycznego programu operacyjnego, zasad polityki UE ${ }^{10}$, trudności wyliczenia montażu finansowego i określenia wskaźników monitoringu czy braku doświadczenia zarządzania projektem.

Jednak zanim beneficjent przygotuje aplikację, powinien zapoznać się z wytycznymi dla wnioskodawców oraz dokumentem programowym (m.in. Zintegrowany Program Operacyjny Rozwoju Regionalnego, Sektorowy Program Operacyjny Wzrost Konkurencyjności Przedsiębiorstw) i specjalnym opracowaniem pt. Uzupełnienie Programu, który uszczegóławia zapisy ZPORR i SPO WKP.

\footnotetext{
${ }^{9}$ Na podstawie Rozporządzenia RM z dnia 11 sierpnia 2004 r w sprawie szczegółowego sposobu obliczania wartości pomocy publicznej udzielanej w różnych formach (Dz. U Nr 194, poz. 1983) oraz Rozporządzenia RM z dnia 1 września 2004 w sprawie ustalenia mapy pomocy regionalnej (Dz. U Nr 200, poz. 2050).

${ }^{10}$ programowania, współfinansowania, dodatkowości, partnerstwa i koncentracji.
} 
Uzupełnienie zawiera informacje o dokumentach, które należy zebrać, aby poprawnie przygotować wniosek. Po skompletowaniu wymaganych dokumentów można przystąpić do przygotowywania wniosku aplikacyjnego. Zanim aplikacja zostanie złożona, należy dokonać wstępnej, samodzielnej weryfikacji i upewnić się, że projekt kwalifikuje się do współfinansowania w zakresie działania zapisanego w uzupełnieniu programu, jak również jest zgodny z celami określonymi w ogłoszeniu o konkursie. Na tym etapie należy precyzyjnie i poprawnie wyliczyć koszty projektu oraz zapoznać się z tzw. montażem finansowym i listą wydatków kwalifikowalnych, która znajduje się w aneksie uzupełnienia programu. Precyzji wymaga również określenie grupy docelowej, jeśli taka występuje oraz przedstawienie wymiernych skutków projektu w postaci wskaźników produktu, rezultatu i oddziaływania. Poprawne wypełnienie wniosku wymaga od projektodawcy przedstawienia wielu danych. Wśród nich należy wymienić podstawowe informacje o projekcie, które określają jego rodzaj, kategorie interwencji oraz obszar i miejsce realizacji, ponadto informacje dotyczące beneficjenta pomocy, ewentualnych podwykonawców i podmiotów zaangażowanych w realizację projektu, harmonogramu realizacji projektu oraz informacji finansowych. Jeśli projektodawca składa więcej niż jeden projekt, we wniosku powinien wskazać informacje o ewentualnym powiązaniu projektu z innymi projektami realizowanymi lub zrealizowanymi przez beneficjenta i finansowanych ze środków przedakcesyjnych, Banku Światowego, Europejskiego Banku Odbudowy i Rozwoju, Europejskiego Banku Inwestycyjnego, a także korzystaniu $\mathrm{z}$ innych funduszy strukturalnych lub kontraktu wojewódzkiego.

Ważne jest, by duże projekty podzielić na kilka etapów, wtedy po realizacji każdego $\mathrm{z}$ nich będzie można ubiegać się o refundację. Dzięki temu nie trzeba się martwić, skąd w trakcie realizacji, wziąć środki na dalsze finansowanie projektu.

Ponadto wraz z wnioskiem należy złożyć inne dokumenty m.in. wypis z Krajowego Rejestru Sądowego lub Ewidencji Działalności Gospodarczej, poświadczające sytuacje finansową beneficjenta; zaświadczenie o niezaleganiu z podatkami z urzędu skarbowego; w przypadku projektów infrastrukturalnych decyzję zawierającą pozwolenie na budowę oraz dodatkową dokumentację wymaganą w zależności od funduszu. Kiedy aplikacja zostanie przygotowana, wniosek wraz z załącznikami należy złożyć we właściwej z punktu realizacji projektu instytucji wdrażającej (urząd marszałkowski, RIF) w formie papierowej i elektronicznej.

Aby mogła zostać udzielona dotacja, wniosek musi zostać pozytywnie oceniony w oparciu o 3 kryteria:

1) kwalifikacyjne: wnioskodawca i jego projekt muszą spełniać kryteria ubiegania się o dotację,

2) formalne: wniosek musi być kompletny i złożony we właściwym terminie,

3) merytoryczne: obejmuje jakościową ocenę projektu wnioskodawcy, czyli m.in. celów i rezultatów planowanych działań, adekwatności zaplanowanego budżetu do podejmowanych działań.

Należy pamiętać, że miarą wykorzystania środków z funduszy strukturalnych nie jest ilość zdobytych pieniędzy, procent zaabsorbowania funduszu, lecz efekty poczynionych inwestycji. Dlatego ważne jest, aby projekt nie był inwestycją, której realizacja przestanie być kontynuowana wraz z zakończeniem przyznawania unijnej dotacji. Kryterium trwałości projektu jest bardzo ważne przy ocenie wniosku i zanim do tego dojdzie, należy ocenić wartość i poprawność przygotowania projektu.

Projektodawcy powinien przyświecać podstawowy cel: nie można tworzyć projektu pod konkretne programy operacyjne, lecz środki strukturalne powinny wspomóc realizację inwestycji. 


\section{PoDsumowanie}

Rozwój przedsiębiorczości ma fundamentalne znaczenie dla sukcesu gospodarczego kraju jako całości. Realizacja nowych przedsięwzięć, zarówno przez przedsiębiorstwa nowo powstałe, jak i te restrukturyzowane, prowadzi do wzrostu produktywności i konkurencyjności na rynku, co zmusza również inne firmy do realizacji inicjatyw poprawiających ich efektywność lub reorientacji ich działalności. Poprawa konkurencyjności poszczególnych firm pozytywnie oddziałuje na całą gospodarkę. Jej skutki odczuwają również inni uczestnicy rynku. Rozwój przedsiębiorczości jest więc kluczowy dla osiągnięcia wysokiego tempa rozwoju gospodarczego w długim okresie, wzrostu międzynarodowej konkurencyjności całej gospodarki, a także osiągnięcia wysokiego poziomu zatrudnienia i niskiego poziomu bezrobocia.

Podstawowym warunkiem rozwoju przedsiębiorczości w Polsce jest stworzenie odpowiedniego otoczenia makroekonomicznego, prawnego i instytucjonalnego pozwalającego jednostkom na prowadzenie i rozwijanie działalności gospodarczej. Ważny jest sposób, w jaki rynek na którym działają jest zorganizowany. Z badań Banku Światowego wynika, że im liczniejsze i ostrzejsze są prawne regulacje rynku, tym niższa jest produkcja, a wyższe: korupcja, koszty funkcjonowania przedsiębiorstw oraz czas poświęcony na wypełnianie obowiązków wobec państwa. W Polsce, pomimo ogromnego postępu, jaki można było zaobserwować od początku lat 90 . w zakresie tworzenia środowiska przyjaznego przedsiębiorcom oraz wspierania przedsiębiorczości, z których ostatnim, bardzo ważnym - jest Ustawa o swobodzie działalności gospodarczej - nadal istnieją znaczne potrzeby w tym zakresie.

W krajach „starej” UE-15 działa około 19 milionów przedsiębiorstw z sektora MŚP. Biorąc pod uwagę także pozostałe państwa Europy Zachodniej, nie będące członkami UE (Norwegia, Liechtenstein i Szwajcaria) liczba przedsiębiorstw z sektora MŚP wzrasta do 21 milionów, dając zatrudnienie w sumie ponad 117 mln mieszkańców. Dane te obrazuję jak ogromną siłę stanowią małe i średnie przedsiębiorstwa w Europie (Biuletyn Euro Info dla małych i średnich firm, 2001).

Integracja regionów Polski z UE stanowi dla nich wyzwanie i sprawdzian konkurencyjności. To od konkurencyjności polskich regionów i przedsiębiorstw w nich działających zależeć będzie czy strona polska wykorzysta szanse, jakie stwarza wejście do jednolitego, unijnego rynku. Im silniejszy będzie transfer technologii do Polski z UE, im szybciej technologia ulegnie rozpowszechnieniu na polskim rynku w wyniku efektów naśladownictwa i uczenia się, tym korzystniejszy będzie bilans kosztów i korzyści integracji dla Polski.

Jak wskazują doświadczenia krajów Unii Europejskiej, wiedza oraz potencjał technologiczny nie wykazują tendencji do konwergencji regionalnej. Liczyć należy się raczej $\mathrm{z}$ jeszcze większą koncentracją potencjału technologicznego wokół istniejących już dzisiaj silnych ośrodków technologicznych, badawczo-rozwojowych oraz w parkach technologicznych zlokalizowanych w specjalnych strefach ekonomicznych.

W latach 1990-2000 Komisja Europejska przydzieliła krajom kandydującym blisko 7,6 miliardów euro, z czego prawie 1 miliard euro ${ }^{11}$ przeznaczono na bezpośrednie wsparcie na rzecz MSP, rozwój sektora prywatnego i restrukturyzację.

Nowe państwa członkowskie w latach 2004-2006 mogą już korzystać z funduszy strukturalnych w wysokości ok. 21,9 miliarda euro, z czego 13 mld euro przypada dla Polski.

Duża część tych środków zostanie przeznaczona na "pomoc dla sektora produkcyjnego", tzn. na działania związane z rozwojem przedsiębiorczości, co oznacza, że fundusze strukturalne staną się w nadchodzących latach jednym z najważniejszych źródeł finansowania działań w ramach programów wspierających przedsiębiorczość.

\footnotetext{
${ }^{11}$ Kwota ta odnosi się do działań skupiających się zwłaszcza na rozwoju przedsiębiorstwa, a nie działań na rzecz infrastruktury itp.
} 


\section{LITERATURA}

Bąk M., 2001, Małe i średnie przedsiębiorstwa a rozwój regionalny, Polska Agencja Rozwoju Przedsiębiorczości, Warszawa.

Biuletyn Euro Info dla matych i średnich firm, nr 9 (37), październik 2001 r.

Eichler A., Nowicka-Gorzelańczyk J., 2001, Co czeka przedsiębiorcę po przystapieniu Polski do Unii Europejskiej-swobody gospodarcze, Ministerstwo Gospodarki, Warszawa.

Gawlikowska-Hueckel K., Umiński S., 2000, Ocena konkurencyjności województw, Instytut Badań nad Gospodarką Rynkową, Gdańsk.

GUS, 2004, Nauka i technika w 2003 r., Główny Urząd Statystyczny, Warszawa.

GUS, 2003, Zmiany strukturalne grup podmiotów gospodarki narodowej w 2003 r., Główny Urząd Statystyczny, Warszawa.

Jackson J. E., Klich J., Poznańska K., 2000, Nowe przedsiębiorstwa w transformacji gospodarki polskiej, [w:] Gospodarka Narodowa 5-6/2000, Szkoła Główna Handlowa, Warszawa.

Klamut M., Cybulski L., 2000, Polityka regionalna i jej rola w podnoszeniu konkurencyjności regionów, Akademia Ekonomiczna we Wrocławiu, Wrocław.

NPR, 2004, Narodowy Plan Rozwoju 2004-2006, Ministerstwo Gospodarki i Pracy, Warszawa.

Olechnicka A., 2004, Regiony peryferyjne w gospodarce informacyjnej, Wydawnictwo Naukowe „Scholar”, Warszawa.

Polska Agencja Rozwoju Przedsiębiorczości, 2003, Ustugi wspierające mikroprzedsiębiorstwa, małe przedsiębiorstwa i samozatrudnionych, PARP, Warszawa.

Uzupełnienie Sektorowego Programu Operacyjnego Wzrost konkurencyjności przedsiębiorstw, lata 2004-2006, załącznik do Rozporządzenia Ministra Gospodarki i Pracy z dnia 6 sierpnia 2004 r. (Dz. U. Nr 197 poz. 2023).

Uzupełnienie Zintegrowanego Programu Operacyjnego Rozwoju Regionalnego 2004-2006, załącznik do Rozporządzenie Ministra Gospodarki i Pracy z dnia 25 sierpnia 2004 r. (Dz. U. Nr 200 poz. 2051). 